\title{
Migrations and Growth of the Thornback Ray (Raia clavata L.)
}

By

\author{
G. A. Steven, B.Sc., F.R.S.E., \\ Assistant Naturalist at the Plymouth Laboratory.
}

With 2 Figures in the Text.

\section{INTRODUCTORY.}

Although workers in several European countries (England, Germany, Russia, Scotland) are stated (5) to be carrying out marking experiments on rays or skates, the writer is not aware of any recently published account of the results of any of these researches. Fulton (4, p. 191), however, records that in the years round about 1890 he marked 71 thornback rays (R. clavata) and 23 specimens of grey skate ( $R$. batis) in Scottish waters. Two of the thornbacks and one skate were subsequently recovered. Of the former, one-about $36.5 \mathrm{~cm}$. in width* on marking-remained at liberty for about three months before being recaptured and had travelled about 13 miles from the place where it had been set free. The other$35 \mathrm{~cm}$. in width-remained at liberty for 278 days and travelled about six miles. The single skate, recaptured after only 10 days, had in that time changed its position by 10 miles. No records of size increments are given.

In order to collect data on the migrations and growth-rate of thornback rays in the English Channel, marking experiments have been carried out on certain inshore fishing grounds in the vicinity of Plymouth. For various reasons, not least of which is the high price $\dagger$ of these fish, the numbers involved are somewhat small-compared with those of plaice-marking experiments in the North Sea, for example. Nevertheless, the results already obtained are of such interest that it seems worth while presenting them at this stage.

After considerable preliminary experimentation with several types, a mark consisting of two vulcanite discs, one white and one black, was selected for use. On the white plate the identification letters and serial number are stamped in black (vide 5, p. 139). The mark is placed on the

* In these fishes, width of dise is the most convenient measure of size.

$\uparrow$ Full market value (current price) is paid for a returned fish, in addition to a reward of two shillings if full particulars concerning it are furnished. Rays are prime fish, and as much as seven shillings (inclusive) has had to be paid for the recovery of a marked individual. 
right wing (pectoral fin) of the fish, the white (numbered) plate above and the black one below. It is found that in thus having a white disc on the dark, upper surface and a black one on the white, under side, the mark is more readily observed by fishermen when a marked fish comes on board. This is of especial importance with regard to this laboratory's own research vessel in which, when a haul of fish arrives on deck, a marked individual at once catches the eye and is immediately transferred with all speed to circulating sea-water. If, as is usual, it remains vigorous, it is returned alive to the sea after its measurements have been taken. In this way repeated captures of the same fish have been made and valuable data not otherwise obtainable have been acquired (vide, pp. 609 and 612 infra).

For fishes of about $30 \mathrm{~cm}$. and over in width of disc, mark plates $15 \mathrm{~mm}$. in diameter are used. To all fishes of smaller size mark plates of only $8 \mathrm{~mm}$. diameter are affixed.

\section{Migrations.}

Although rays are only moderately plentiful in the immediate neighbourhood of Plymouth, where these experiments have been carried out, there is one small fishing ground on which at least a few thornback rays can usually be found at all seasons. On this ground, locally known as the "Corner" (vide Fig. 1-shaded area), between 28th November, 1930, and 24th May, 1935, 538 thornbacks have been captured and released again after marking. Releases on other grounds in the vicinity (Fig. 1) have been: Cawsand Bay, 49; Bigbury Bay, 30; Plymouth Sound (inside Breakwater), 7. Of this total of 614 releases, 203 individuals (approximately 33 per cent) have been recaptured after periods varying from 12 to 1357 days. Details of these recaptures are given in Table I.

TABLE I.

Distances Travelled by Recaptured Fish.*

Number recaptured and distance travelled.

Place released.

\begin{tabular}{|c|c|c|c|c|}
\hline \multirow[b]{2}{*}{$\begin{array}{l}\text { Number } \\
\text { released. }\end{array}$} & \multicolumn{4}{|c|}{$\begin{array}{c}\text { Number recaptured and distance } \\
\text { travelled. }\end{array}$} \\
\hline & Stationary. & $\begin{array}{l}\text { Up to } \\
5 \text { miles. }\end{array}$ & $\begin{array}{l}5-20 \\
\text { miles. }\end{array}$ & $\begin{array}{l}20-50 \\
\text { miles. }\end{array}$ \\
\hline 528 & $117^{256}$ & $15^{240}$ & $39^{334}$ & $10^{300}$ \\
\hline 49 & $2^{71}$ & $3^{705}$ & $5^{391}$ & $1^{415}$ \\
\hline 30 & $5^{363}$ & $1^{179}$ & $2^{721}$ & \\
\hline 7 & & $1^{312}$ & $1^{82}$ & \\
\hline 614 & $124^{280}$ & $20^{311}$ & $47^{350}$ & $11^{311}$ \\
\hline
\end{tabular}

From this table it will be seen that of the 202 fishes whose place of recapture is known, no less than 124, or approximately 61 per cent of them,

* Indices refer to average number of days free. 


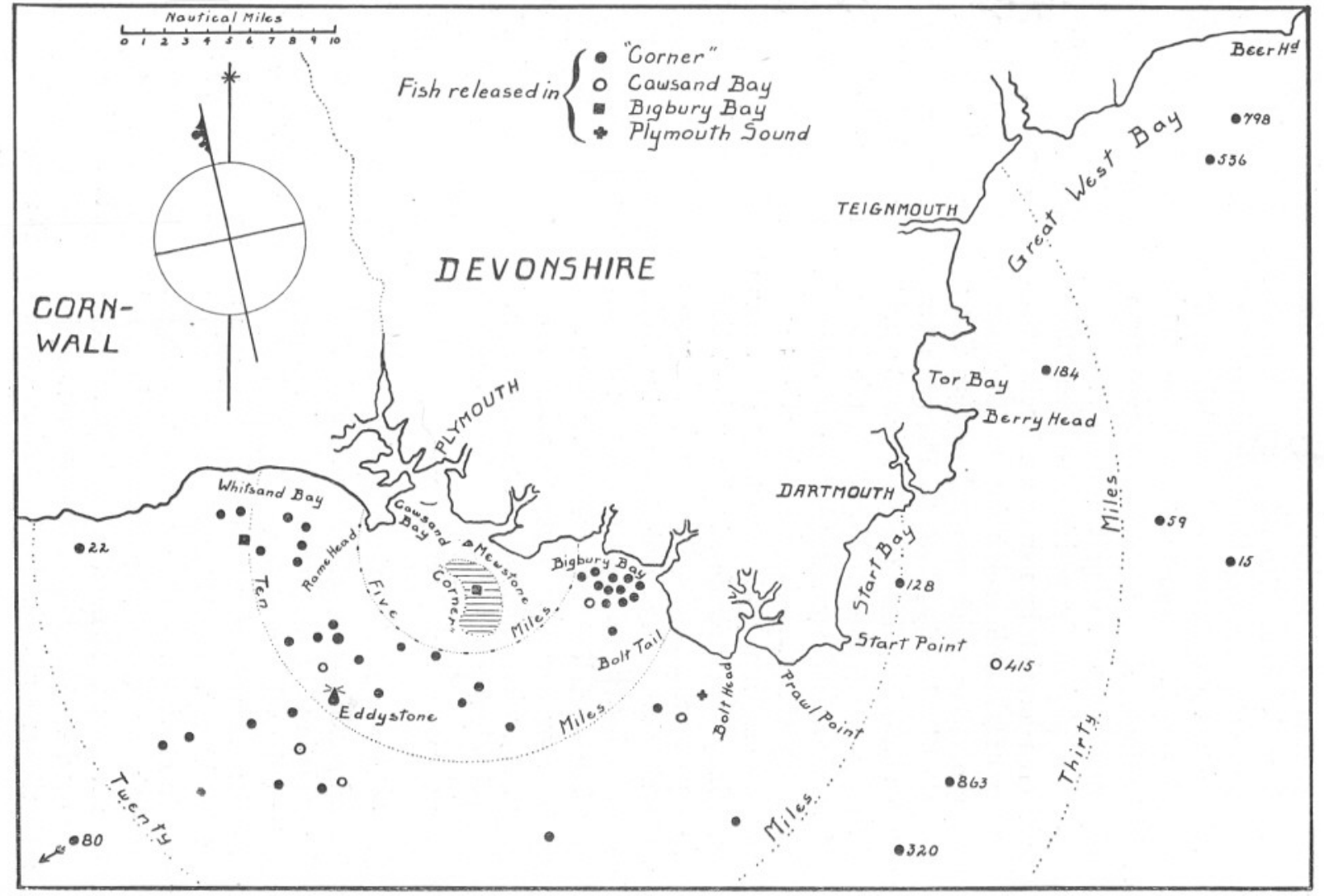

FIG. 1.-Positions of recapture of marked rays which had moved more than 5 miles. Fishes which had exceeded 20 miles have period of liberty shown (in days). For further explanation see text p. 608.

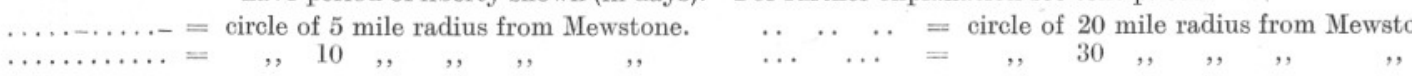

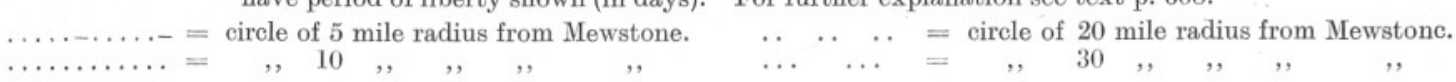


were retaken on the exact spot* where they were set free, and this in spite of the fact that the times which had elasped between marking and recapture again varied from 12 to 1357 days. These returned fish came in at all seasons of the year, and the average period of absence was 280 days. One hundred and forty-four individuals, or 71 per cent of the recaptures, had moved less than 5 miles while only 11 had travelled over 20 miles. Not a single fish has as yet been returned from a distance greater than 50 miles from the point where it was set free.

In Figure 1 are plotted the positionst of recapture of all fishes which had changed their location by more than 5 miles, the different symbols indicating place of release in each instance. The great majority of these recaptures are of fishes which were released on the "Corner" ground (closed circles). Six had been set at liberty in Cawsand Bay (open circles); two in Bigbury Bay (closed squares); and two just inside Plymouth Breakwater (crosses). Bearing in mind that 144 fishes which had moved less than 5 miles are not plotted on it, examination of Figure 1 shows very clearly that there is no definite migratory movement of fish from these grounds. It must be noted, however, that most of the fish marked were immature individuals. Throughout their growing period, therefore, the young thornbacks show no migratory movement. There is simply a very slow diffusion of some fishes outwards in all directions.

Unfortunately, because of their scarcity on the trawling grounds, a sufficient number of adult thormbacks has not been marked to yield data concerning their movements. There is evidence from other sources, however $(1$, p. 20$)$, which suggests that a certain amount of migratory movement (probably not very extensive) is shown by the sexually mature fish. A special effort is now being made to trace the extent of these migrations.

Because of the very marked non-migratory habit of the young fish it has been found possible to capture the same individual more than once at varying intervals in the same place. Of the 150 fishes which had moved less than five miles subsequent to marking, 23 have been recaptured by our own vessel, measured, and returned alive to the sea where, presumably, they are still at liberty. In addition, 10 fishes have been recaptured more than once. In one instance the same fish was caught by the Salpa no fewer than 4 times within a year after it had been marked, at intervals varying from 13 days to $4 \frac{1}{2}$ months. This fish, therefore, was on a ship's deck five times within 12 months, having been trawled up on each occasion from exactly the same place in about 25 fathoms of water. It was caught

* i.e. as nearly as can be ascertained at sea. As the grounds in question are all close by the land, the positions were fixed with considerable accuracy by the use of landmarks on shore.

$\dagger$ One fish was recaptured beyond the limits of this chart at a point 22 miles farther on, in the direction indicated by the arrow. 
again a sixth time, still in the same place, 14 months after marking. Unfortunately, on this final occasion the capture was effected by a commercial vessel which killed it. Details of this and other repeat captures are given in Table II.

TABLE II.

Records of Repeat Captures.

\begin{tabular}{cccccccc} 
Serial & Date & \multicolumn{9}{c}{ Dates recaptured. } & & $\begin{array}{c}\text { Whether } \\
\text { released } \\
\text { No. }\end{array}$ & marked. & I & II & III & IV & V & again. \\
12 & $13 / 2 / 31$ & $8 / 4 / 32$ & $10 / 5 / 33$ & & & & No \\
30 & do. & $5 / 2 / 32$ & $22 / 5 / 32$ & & & & Yes \\
51 & $10 / 10 / 31$ & $8 / 12 / 31$ & $21 / 12 / 32$ & $29 / 3 / 33$ & & & Yes \\
63 & do. & $9 / 2 / 32$ & $6 / 8 / 35$ & & & & No \\
68 & do. & $24 / 8 / 32$ & $26 / 9 / 33$ & & & & No \\
133 & $23 / 12 / 31$ & $22 / 1 / 32$ & $14 / 5 / 32$ & $13 / 9 / 32$ & & & Yes \\
226 & $25 / 4 / 32$ & $22 / 5 / 32$ & $25 / 8 / 32$ & $5 / 1 / 33$ & $18 / 1 / 33$ & $1 / 7 / 33$ & No \\
285 & $12 / 5 / 32$ & $29 / 7 / 32$ & $7 / 12 / 32$ & & & & No \\
$103 \mathrm{~S}$ & $25 / 4 / 32$ & $22 / 3 / 33$ & $26 / 1 / 34$ & $23 / 4 / 34$ & & & Yes \\
$143 \mathrm{~S}$ & $12 / 5 / 32$ & $15 / 7 / 32$ & $2 / 8 / 32$ & & & & No
\end{tabular}

All the fishes recorded in the above table were captured and released on the "Corner" grounds in from 20 fathoms to 25 fathoms of water, and all except one were in every instance recaptured exactly where they had been originally set free. The single exception was No. 63 which, in the interval between its second and third (final) captures, had moved to Bigbury Bay. Where in this table fishes are recorded as being no longer at liberty it means that, on the final occasion of their capture, they were taken by a commercial vessel and returned dead to this laboratory. Those still at liberty were on every occasion taken by the laboratory's research vessel and returned alive to the sea after measuring.

It is important further to note that all of the fishes included in Table II -except No. 63-were immature at the time of marking and were still immature at the time of their final recapture, the largest, a female (No. 285), being then approximately $49.5 \mathrm{~cm}$. in disc width. The single individual (No. 63) which on its final capture was found to have moved a few miles away was an adolescent female $64.5 \mathrm{~cm}$. in width.

In trawling for rays for marking purposes each haul has seldom been less than 1 hour and never exceeded 2 hours in duration. That numerous fish have survived repeated capture, as recorded in Table II, indicates that they can successfully withstand pretty severe treatment. But still further, and at first rather unexpected, evidence of their capacity to withstand rough handling has been obtained. During marking operations, immediately after a catch of fish has been brought on board, the trawl frequently has been lowered again at once and the captured fish marked and released while fishing continued in progress. This is now the routine method of working. In these circumstances it occasionally happens that 
a newly marked fish goes straight to the bottom and is caught again forthwith in the advancing trawl.* Most fishes taken twice in rapid succession in this way have survived the double capture and several have been caught again after further periods of liberty. One individual (222 S), a young male $22.5 \mathrm{~cm}$. in width, was caught and brought on board three times on the day of marking and, having survived, was finally released only to be taken yet again after an interval of approximately 11 months. Details of this and other repeat captures on the day of marking, and the further history of each fish, are given in Table III.

\section{TABLE III.}

\section{Repeat Captures on Day of Marking.}

Serial No.

$222 \mathrm{~S}$.

209

266

397
Details of capture on day of marking.

Retaken twice, after marking, in consecutive hauls of the trawl.

242 S. Retaken once after first release on day of marking.

Do.

In addition, eleven other individuals have been retaken once after first release on the day of marking but have not been heard of again.

Three small thornbacks, however, each under $14 \mathrm{~cm}$. in width, which at different times were taken in consecutive hauls, failed to recover after the second capture. Only on one occasion has a larger fish (48 cm. wide) failed to recover after two captures. This fish, when it arrived on deck the second time, received a severe knock from a large stone which had found its way into the cod end, the injury so received being the probable cause of death.

It is hoped to carry out further tests on the survival powers of rays of different species. The results so far obtained, however, suggest that where these fishes form an important part of the catch-as in English Channel

\footnotetext{
* Rays returned to the sea after having been in the trawl, irrespective of whether or not they have been marked, usually swim about at the surface for a considerable time before descending to the bottom.
} 
waters - it would well repay commercial trawl-fishing vessels to take the shortest possible hauls which are consistent with fishing efficiency, and to return at once to the sea all rays which are too small to be marketable. Possibly the very smallest individuals might not recover, but the larger unmarketable sizes would almost certainly live. Being non-migratory, these young fish would remain on the same grounds until they reached saleable size; they would not move away to another area where other fishermen (perhaps less careful of their own stocks) would reap the benefit. The non-migratory habit of these fishes in their growing stages, coupled with a relatively long juvenile life (vide p. 614 infra) is also important in that it increases the possiblity of reducing the stock on any particular fishing ground by too intensive fishing. Unlike migratory species which are exposed to capture only for so long as they remain in a fishable area, and whose numbers tend to be sustained or replenished by immigrants from other localities, the rays present on fishable ground remain constantly exposed to capture, and their numbers will be augmented only very slowly by gradual infiltration of individuals from adjacent regions where fishing is impossible or less intense.

\section{GRowTH.}

Of the 202 recaptured fish whose place of recapture is known, figures relating to size* have been received for 197 of them. Ten of these have been captured more than once and more than one record of growth has been obtained.

In Table IV the mean growth increments grouped at monthly intervals for fishes of $10-\mathrm{cm}$. size groups are given, the indices denoting the numbers of fish upon which the entries are based. Only 2 fishes of the very smallest size group $(10-19.5 \mathrm{~cm}$.) have been returned. It would seem that many of these very small individuals do not survive the ordeal of marking although returned to the sea in very vigorous condition. Notwithstanding that the smaller of the two marks in use is invariably affixed to them, it is relatively an enormous encumbrance to such tiny fishes, not to mention the relative severity of the operation when placing it in position. The use of a still smaller mark is impracticable.

At the other end of the scale, only very few fishes over $60 \mathrm{~cm}$. disc width have been marked, and only one returned. As mentioned above, most of the fishes present on the Plymouth grounds are immature individuals and it is therefore mainly to those sizes, from about $20 \mathrm{~cm}$. to $50 \mathrm{~cm}$. disc width, that the data so far collected apply.

Examination of Table IV shows that, over this range-although there is considerable variation in the data owing to individual differences in

\footnotetext{
* All measurements are made to the nearest half-centimetre next below.
} 
growth rate-both sexes grow at a rate of from slightly under $4 \mathrm{~cm}$. to slightly over $8 \mathrm{~cm}$. in width of disc in the course of a full year.

In Figure II the growth increments of fishes which several times have

\section{TABLE IV.}

\section{Mean Size Increments of Marked Raia clavata.}

Grouped at monthly (=4-weekly) intervals. Size increments in $\mathrm{cm}$. Indices denote numbers of fish upon which entries are based when more than one.

\begin{tabular}{|c|c|c|c|c|c|c|c|c|c|c|c|c|}
\hline Months & & & & & & Size & group & (cm.). & & & & \\
\hline at & & $0-19 \cdot 5$ & . $20-2$ & $29 \cdot 5$ & $30-$ & $-39 \cdot 5$ & 40 & $-49 \cdot 5$ & 50 & $59 \cdot 5$ & $60-69 \cdot 5$ & \\
\hline liberty. & $\hat{\sigma}$ & 웅 & ô & 우 & $\hat{0}$ & 우 & $0 ే$ & 우 & $\widehat{0}$ & 우 & $\hat{0}$ 우 & \\
\hline 0 & & & $0 \cdot 17^{6}$ & $0 \cdot 0^{4}$ & $0 \cdot 3^{2}$ & $0 \cdot 0^{4}$ & $0 \cdot 0^{2}$ & $0 \cdot 2^{3}$ & $0 \cdot 5^{2}$ & $0 \cdot 0$ & & \\
\hline 1 & & & & $0 \cdot 1^{4}$ & $0 \cdot 5^{5}$ & & & & $1 \cdot 3^{2}$ & $0 \cdot 0$ & & \\
\hline 2 & & & $0 \cdot 5$ & 0.5 & $2 \cdot 3^{2}$ & $1 \cdot 2^{3}$ & $0 \cdot 5$ & & & $0 \cdot 3^{2}$ & 0.5 & \\
\hline 3 & & & $1 \cdot 2^{3}$ & & $2 \cdot 0^{3}$ & $1 \cdot 2^{3}$ & $0 \cdot 5^{2}$ & & $0 \cdot 0$ & $2 \cdot 0$ & & \\
\hline 4 & & & $2 \cdot 0^{2}$ & & $1 \cdot 5^{2}$ & $1 \cdot 8^{3}$ & $1 \cdot 0$ & $0 \cdot 5^{3}$ & & $1 \cdot 0$ & & \\
\hline 5 & & & & & $0 \cdot 5$ & $1 \cdot 0$ & $3 \cdot 0$ & & & $2 \cdot 0^{2}$ & & \\
\hline 6 & & & $0 \cdot 0$ & $3 \cdot 0$ & $3 \cdot 1^{3}$ & $3 \cdot 0$ & & $0 \cdot 5$ & $2 \cdot 0$ & $3 \cdot 0^{2}$ & & ] \\
\hline 7 & & & & $1 \cdot 5$ & $2 \cdot 5^{2}$ & $4 \cdot 2^{3}$ & $3 \cdot 8^{2}$ & $3 \cdot 5$ & & & & \\
\hline 8 & & & $3 \cdot 3^{2}$ & & $3 \cdot 5$ & & $2 \cdot 5$ & $3 \cdot 0^{2}$ & & & & 一 \\
\hline 9 & & & $6 \cdot 0$ & $4 \cdot 5$ & $5 \cdot 0$ & $3 \cdot 3^{3}$ & & $5 \cdot 2^{3}$ & $0 \cdot 5$ & & & \\
\hline 10 & & & $5 \cdot 0$ & & & $4 \cdot 5$ & & $5 \cdot 5$ & $3 \cdot 5$ & $6 \cdot 5$ & & \\
\hline 11 & & & $2 \cdot 5$ & & $3 \cdot 5$ & $3 \cdot 0^{2}$ & $3 \cdot 0$ & $6 \cdot 5$ & $5 \cdot 0$ & & & \\
\hline 12 & & & & $4 \cdot 5$ & $8 \cdot 0$ & $3 \cdot 0$ & & & & & & \\
\hline 13 & & & $5 \cdot 5$ & & & & $5 \cdot 5^{2}$ & & & & & \\
\hline 14 & & & $7 \cdot 3^{2}$ & & 7.5 & $\begin{array}{l}4 \cdot 5^{2} \\
7 \cdot 3^{2}\end{array}$ & & $6 \cdot 5$ & & 9 & & \\
\hline $\begin{array}{l}15 \\
16\end{array}$ & & 5.5 & & & $9 \cdot 0$ & 11.5 & $5 \cdot 5$ & & $5 \cdot 5$ & $3 \cdot 8^{2}$ & & \\
\hline $\begin{array}{l}16 \\
17\end{array}$ & & & $8 \cdot 3^{2}$ & & $5 \cdot 5$ & $7 \cdot 0^{2}$ & & & & $3 \cdot 8^{2}$ & & \\
\hline 18 & & & $8 \cdot 0$ & & & & & $8 \cdot 0$ & & & & \\
\hline 19 & & & & & $9 \cdot 8^{3}$ & $16 \cdot 0$ & $7 \cdot 5$ & $9 \cdot 5$ & & & & \\
\hline 20 & & & & & $7 \cdot 5$ & & & & & $11 \cdot 5$ & & \\
\hline 21 & & & & & & $4 \cdot 5$ & $10 \cdot 5^{2}$ & $6 \cdot 0$ & & & & $\hat{N}$ \\
\hline 22 & & & & & & & $5 \cdot 5$ & & & & & \\
\hline 23 & & & & & $4 \cdot 5$ & & & & & & & \\
\hline $\begin{array}{l}24 \\
25\end{array}$ & & & $17 \cdot 0$ & & $12 \cdot 0$ & & $5 \cdot 5$ & & & & & \\
\hline $\begin{array}{l}25 \\
26\end{array}$ & & & & $16 \cdot 0$ & & & & & & & & \\
\hline $\begin{array}{l}26 \\
27\end{array}$ & & & & & & & & & & $18 \cdot 0$ & & \\
\hline $\begin{array}{l}27 \\
28\end{array}$ & & & & & & & & $13 \cdot 0$ & & & & \\
\hline 30 & & & & & & $17 \cdot 5$ & & & & & & \\
\hline 31 & & & & & & & $7 \cdot 8^{2}$ & & & & & \\
\hline 33 & $7 \cdot 5$ & & & & & & & & & & & \\
\hline 34 & & & & & & $6 \cdot 5$ & $12 \cdot 5$ & & & $11 \cdot 5$ & & 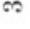 \\
\hline 36 & & & & & & $16 \cdot 5$ & $12 \cdot 0$ & & & & & \\
\hline $\begin{array}{l}39 \\
43\end{array}$ & & & & $13 \cdot 0$ & & 31.0 & & & & & & \\
\hline 45 & & & $23 \cdot 0$ & & & & $9 \cdot 0$ & & & & & 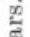 \\
\hline 48 & & & & $29 \cdot 5^{2}$ & & & & & & & & \\
\hline 52 & & & & & & & & & & & & \\
\hline
\end{tabular}

been captured are shown graphically.* From this figure it will be seen that fishes No. 30, 51, 133, 226, and $103 \mathrm{~S}$, which happened to be caught

* It should be noted that the lines joining the points plotted in this graph are inserted simply to facilitate reference to the several records for each fish; they have no mathematical significance. 


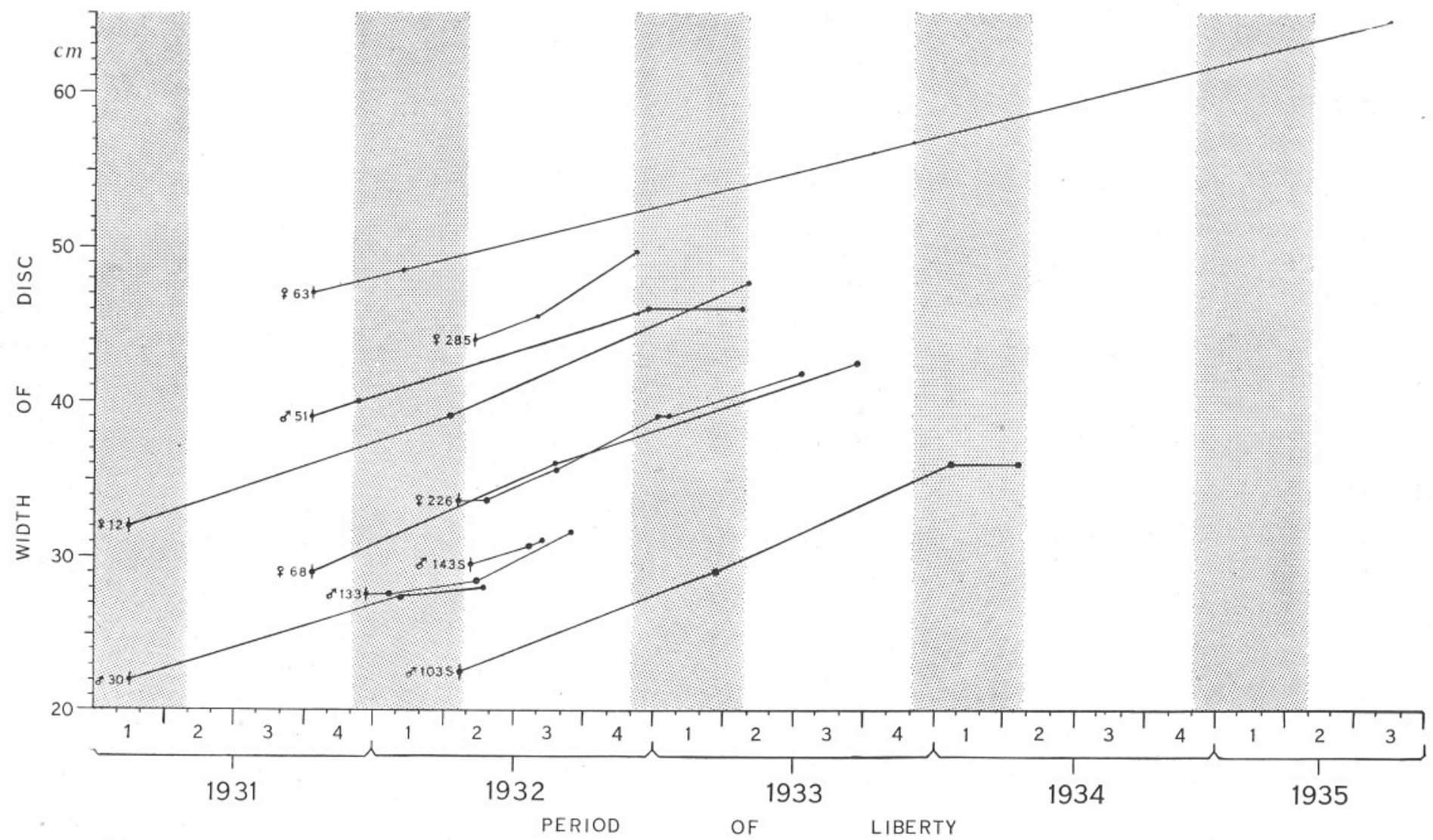

Fig. 2.-Growth of fishes for which more than one record has been obtained. The sex and serial number of each fish are given. Stippled areas= winter (non-growing) periods. $\quad$ indicates first measurement and time of marking. 
twice in the course of a winter period, show little or no growth in the winter interval. This winter period of slackened growth rate appears to extend from about the beginning of December until the end of April.

From this figure, too, it will be seen that the rate of growth in both sexes is approximately the same over the size range represented. For reasons already stated no data are available from marking experiments on the growth rates of the largest size groups. Observations on market categories (3, pp. 890 et seq.), however, reveal that in the males firstmaturity is reached at or shortly after a disc width of $50 \mathrm{~cm}$. is attained, and that thereafter their growth rate rapidly falls off. Male thornbacks seldom exceed and usually fail to reach $60 \mathrm{~cm}$. disc width.

The females, on the other hand, do not reach first-maturity until they have attained a disc width of from 65 to $70 \mathrm{~cm}$., and old adults of over $80 \mathrm{~cm}$. disc width are not uncommon. Since both sexes grow at about the same rate until the male reaches first-maturity it follows that the males become adult at a younger age than the females. Thornback rays hatch out from the egg having an average disc width of approximately $8 \mathrm{~cm}$. (1, p. 595). Taking $6.0 \mathrm{~cm}$. per annum as an average growth rate in both sexes until the onset of sexual maturity, it follows that the males reach this stage when they are about 7 years of age whereas the females do not become sexually mature for another 2 years or so.

\section{LITERATURE CITED.}

1. Clark, Robert S. Rays 'and Skates (Raiæ). No. 1. Egg Capsules and Young. Jour. Mar. Biol. Assoc., Vol. XII, No. 4, p. 577. 1922.

2. Steven, G. A. Rays and Skates of Devon and Cornwall. II. A Study of the Fishery; with Notes on the Occurrence, Migrations and Habits of the Species. Jour. Mar. Biol. Assoc., Vol. XVIII, No. 1, p. 1. 1932.

3. _- Observations on the Growth of the Claspers and Cloaca in Raia clavata L. Jour. Mar. Biol. Assoc., Vol. XIX, No. 2, p. 887. 1934.

4. Fulton, T. Wemyss. An Experimental Investigation of the Migrations and Rate of Growth of the Food Fishes. Eleventh Ann. Rept., Fishery Board for Scotland, pt. III, p. 176. (1892), 1893.

5. Russell, E. S. (Edit.). A Guide to Fish Marks. Journal du Conseil, Vol. VII, No. 1, p. 133. 1932. 